

\title{
The genesis of urnfields: economic crisis or ideological change?
}

\author{
HARRY FOKKENS*
}

CC intro: The genesis of urnfield cemeteries and of Late Bronze Age culture change is often related to an economic and environmental crisis. In the Lower Rhine Basin, changes in burial rites, settlement structure and hoarding practices show a transformation of ideology, consistent with the dissolution of a society into smaller, more autonomous social units.

In most parts of continental Europe, the first appearance of urnfields marks the beginning of a new archaeological period: the Late Bronze Age. The development of large cemeteries, often with hundreds of cremation graves, signified a fundamental break with the burial practice of the earlier period: a single inhumation or cremation grave covered by an earthen burial mound. At the same time many new types of pottery were introduced which in fabric, form and decoration differed completely from their Middle Bronze Age predecessors.

For a long time there has been hardly any debate about the explanation for these changes: the obvious answer was: migration. The author of this theory, Gordon Childe, showed that not only in temperate Europe, but also in Asia and the Mediterranean, crises prevailed at the beginning of the 12 th century $\mathrm{BC}$. The Mycenaean civilization and the Hittite empire collapsed, the Greeks were invaded by the Dorians, and other barbarian tribes raided the Levant and Egypt. In Childe's view (1958: 178) it seemed ‘...p plausible to connect these barbarians with the practice of cremation and burial in urnfields and also with the habit of wearing safety-pins'. In other words, the barbarians originated from the core area of the urnfields, central Europe, with the Lausitz culture as the probable mother culture.

Nowadays the migration paradigm has been abandoned as a general explanation. Since the 1970 s social change has become the magic ex- planatory concept. But social change does not occur spontaneously. It has to be triggered by something. Since the development of the New Archaeology, more often than not economic processes or crises have been identified as triggers. This has also been the case with respect to the changes in material culture that mark the beginning of the Late Bronze Age in many areas of northwestern and central Europe. Yet economic crises are difficult to demonstrate and in the identification process use is often made of circumstantial evidence derived from archaeological and ecological data. Moreover, economic crises mostly fail to explain ideological aspects of culture, for instance changes in burial rites, hoarding practices, etc.

In this paper, I will argue that an economic crisis was not the main reason for Late Bronze Age culture change, but rather a social and ideological transformation that first became visible in the burial practices. Instrumental in this transformation was, in my opinion, the expansion of the exchange networks. The processes I try to describe and explain are derived from data in the Lower Rhine Basin, but of course they are related to processes that occurred within the larger framework of the northwest European plain. As such the implications of this article reach farther then the Low Countries, but only in general terms.

First I will introduce the reader to three categories of data: burials, settlements and bronze exchange. These categories have often been

\footnotetext{
* Faculty of Archaeology, Leiden University, PO Box 9515, 2300 RA Leiden, The Netherlands. E-mail: H.Fokkens@arch.leidenuniv.nl
}

Received 14 January 1997, accepted 4 February 1997, revised 27 March 1997. 


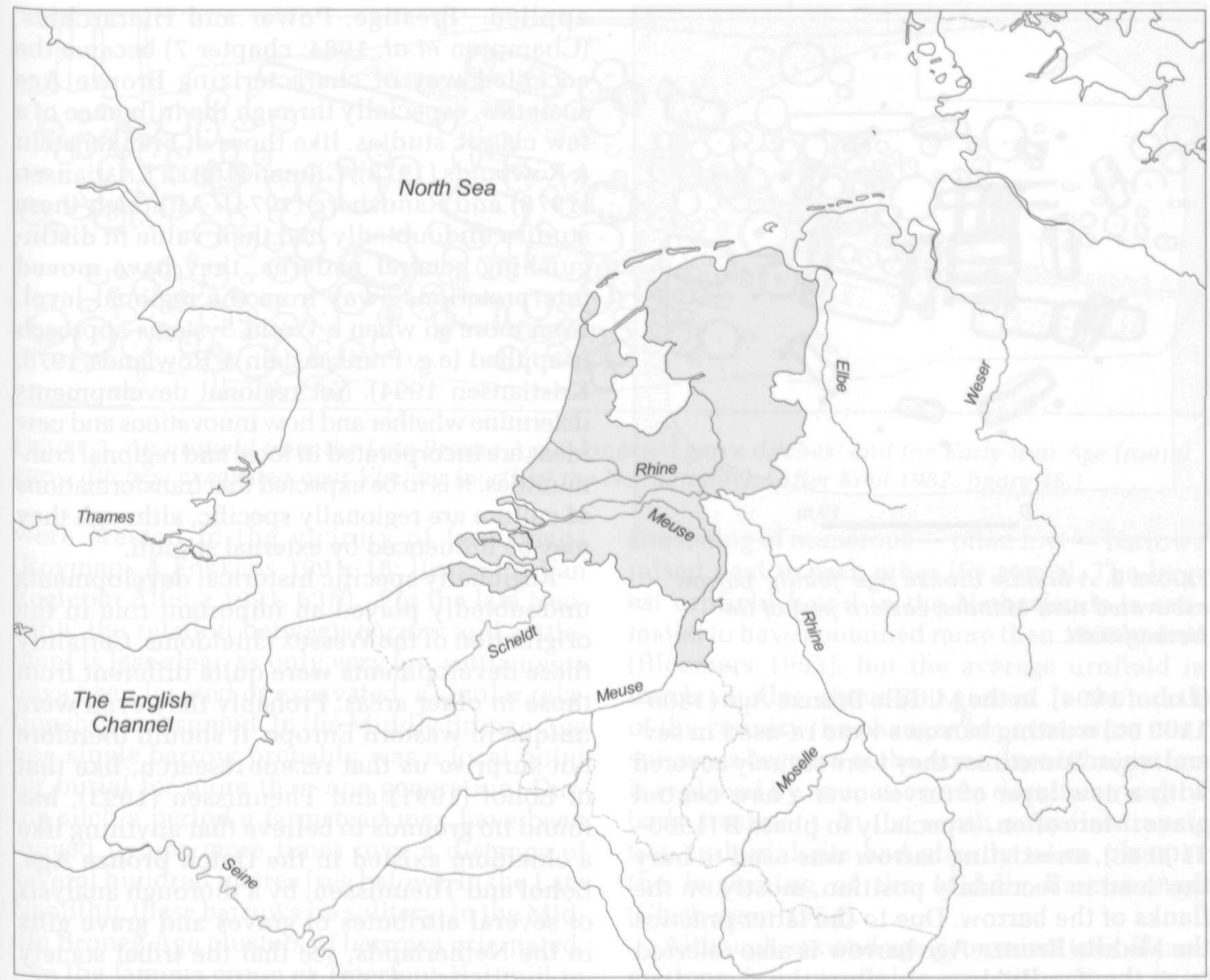

FIGURE 1. A map of northwestern Europe, indicating the most important waters. The Netherlands are indicated in grey, the borders between countries as dotted lines.

treated separately: in this study I explore how the transformations that we witness in these realms of material culture can be explained in coherence with each other.

\section{Case study: the Lower Rhine Basin}

In the Netherlands the first urnfields occur $c$. $1100 \mathrm{BC}$, in the north and the northeast probably a little earlier than in the Middle and the South (Van den Broeke 1991: 194). This regional difference between the areas north and south of the delta of the rivers Rhine and Meuse, a constant feature since the Neolithic, is in the Middle Bronze Age expressed in the distinction between two archaeological cultures: the Elp culture in the north and the Hilversum culture in the south (FIGURE 1). The north has affinities with Scandinavia and north(western)
Germany, the south with the Belgian lowlands, northern France and the adjoining German area. This division did not lead to large cultural differences, but in many respects regional variations are traceable.

\section{Burial rites: dispersed 'hierarchical'} barrows replaced by 'democratic' urnfields From the Late Neolithic until the Late Bronze Age, the earthen barrow was the dominant form of burial monument in the Low Countries. Flat graves, i.e. graves without a covering barrow, are relatively few in number. In the Late Neolithic (2900-2000 BC) and in the Early Bronze Age (2000-1800 BC) the barrows contained only one central grave, usually an inhumation grave. No secondary use of these barrows has been attested from the same chronological period 


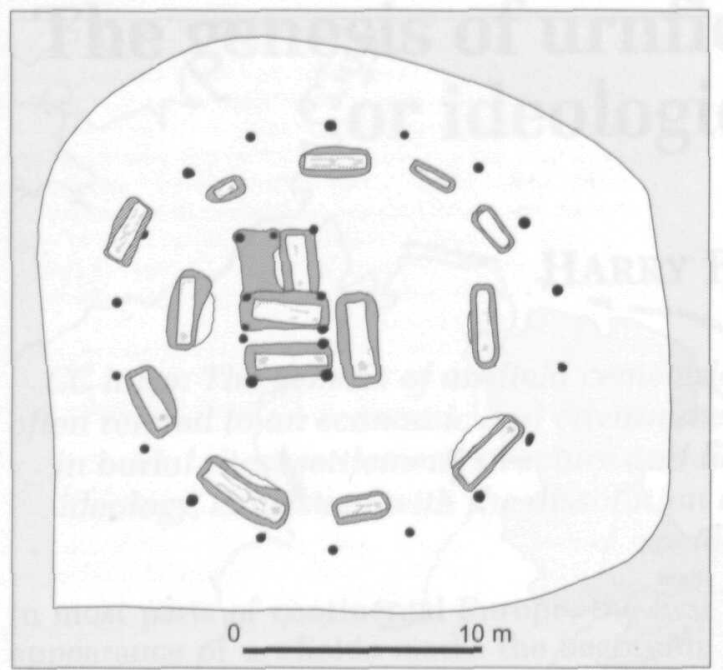

Figure 2. A Middle Bronze Age 'family' barrow excavated near Mander, eastern part of the Netherlands.

(Lohof 1994). In the Middle Bronze Age (1800$1100 \mathrm{BC}$ ) existing barrows were re-used in several ways. Sometimes they were entirely covered. with a new layer of turves over a new central grave. More often, especially in phase B (1500$1100 \mathrm{BC}$ ), an existing barrow was used to bury the dead in secondary position, mostly on the flanks of the barrow. Due to the latter practice the Middle Bronze Age barrow is also referred to as the 'family' barrow, since the secondary graves are supposed to belong to the direct descendants of the person who is in the primary grave (FIGURE 2). Lohof (1994: 114) and Theunissen (1993), who recently made detailed analyses of the social aspects of burial rites in the Netherlands, think that the majority of these graves can be attributed to women and children.

It is quite obvious that not every person was entitled to be buried in a primary or even a secondary grave in a barrow. The relatively small number of barrows, the absence of child burials, and the probable under-representation of female burials in primary graves, suggest that predominantly (but certainly not exclusively) elder males were allowed to be buried in those contexts (Lohof 1991; 1994). The question is: who were they?

Since the 1970s the evolutionist answer to this question was almost obvious: they were chiefs! Renfrew's model for the origination of chiefdoms in Wessex (Renfrew 1973) was widely applied. 'Prestige, Power and Hierarchies' (Champion et al. 1984: chapter 7) became the accepted way of characterizing Bronze Age societies, especially through the influence of a few classic studies, like those of Frankenstein \& Rowlands (1978), Gilman (1981), Kristiansen (1978) and Randsborg (1974). Although these studies undoubtedly had their value in distinguishing general patterns, they have moved interpretations away from the regional level. Even more so when a World Systems approach is applied (e.g. Frankenstein \& Rowlands 1978; Kristiansen 1994). Yet regional developments determine whether and how innovations and new ideas are incorporated in local and regional communities. It is to be expected that transformations of culture are regionally specific, although they may be influenced by external stimuli.

Regionally specific historical developments undoubtedly played an important role in the origination of the Wessex chiefdoms. Certainly these developments were quite different from those in other areas. Probably they even were unique in western Europe. It should therefore not surprise us that recent research, like that of Lohof (1991) and Theunissen (1993), has found no grounds to believe that anything like a chiefdom existed in the Dutch Bronze Age. Lohof and Theunissen, by a thorough analysis of several attributes of graves and grave gifts in the Netherlands, see that the tribal society was probably divided into autonomous segments. They are identified as kin groups, directed by elder males. According to Lohof (1994: 114) these kin groups were in the Late Neolithic still united into larger (regional) corporate groups; in the Middle Bronze Age the family barrows show that kin groups based in local communities had become the basic social unit. The people buried in the primary graves underneath barrows are the representatives of these regional or local groups. Their authority was supposedly based on sex, age, their position in the kinship hierarchy, and probably also on special abilities: one had to be 'fit for the job'. Both Lohof and Theunissen think that only 15\% of the population was visibly buried in or underneath a barrow.

Apart from the evidence from the graves themselves, the location of the barrows in the landscape also indicates the importance of the kin group. Settlement data indicate that - at least in the Middle Bronze Age - the barrows 


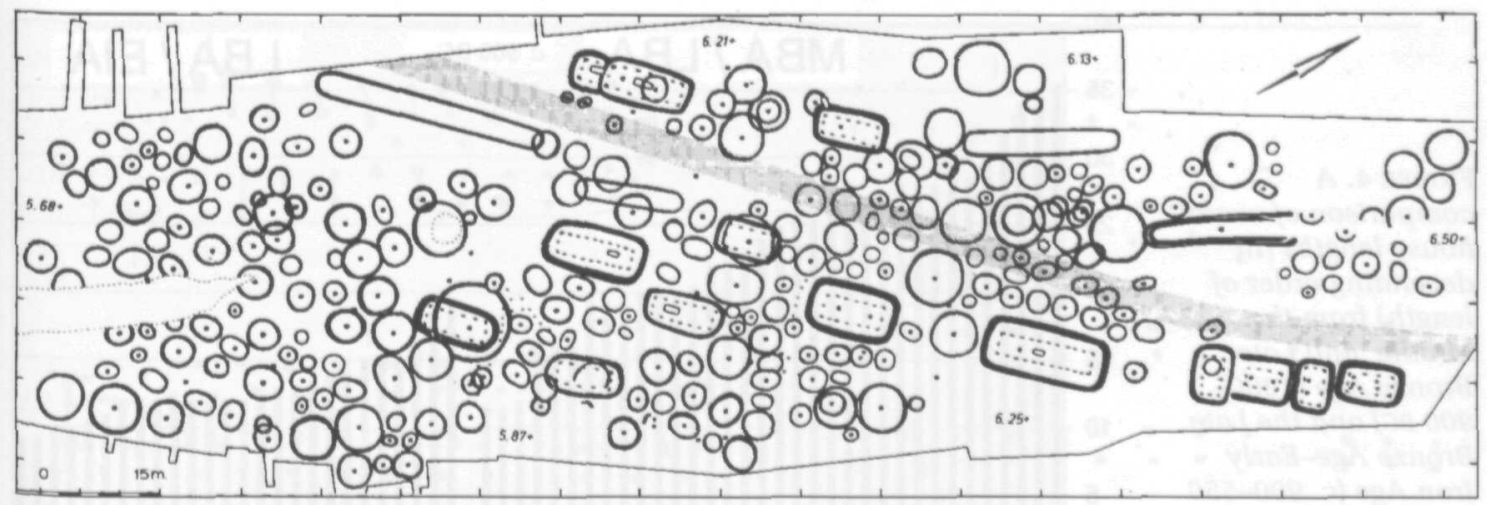

Figure 3. An urnfield from the Late Bronze Age (elongated grave ditches) and the Early Iron Age (round grave ditches) excavated near Vledder (north of the Netherlands). (After Kooi 1982: figure 46.)

were erected in the vicinity of farmsteads (Roymans \& Fokkens 1991: 16; IJzereef \& Van Regteren Altena 1991: 63ff). For the late Neolithic the relation between barrow and settlement is less clear, as only very few settlements have been located or excavated; a similar relationship is assumed. In the Middle Bronze Age one single barrow probably was a focal point for burial for more than one generation. During such a period a farmstead may have been moved two or more times over a distance of several hundred metres (see below). In the Late Neolithic these barrows lie solitary; in the Middle Bronze Age clusters of barrows originated, like the famous group at Toterfout-Halfmijl in the southern Netherlands (Fontijn 1996; Glasbergen 1954; Theunissen 1993).

How did this structure change in the Late Bronze Age? In several ways, but most striking - for us as archaeologists - is the emergence of urnfields. Instead of solitary large barrows with several secondary burials, cemeteries emerged consisting of numerous - often low - barrows raised next to each other (FIGURE 3). The largest urnfield found in the Netherlands is estimated to have contained more than 1000 graves (Bloemers 1993), but the average urnfield is much smaller, about 200 graves. In the north of the country the changes are even more conspicuous because at the same time inhumation is replaced by cremation as a dominant way of body treatment. In the south a similar transition in burial rite had already taken place at the beginning of the Middle Bronze Age (Glasbergen 1954).

Although sex and age determinations of cremations from urnfields are still scarce, it is usually assumed that the urnfield graves represent the entire population. Whether this is true in all respects can be disputed. It is clear, for instance, that not all graves contained only one individual (e.g. Roymans 1988). In general representativeness can be accepted, as long as we are aware that population estimates based on the number of graves in an urnfield will be

\begin{tabular}{|c|c|c|}
\hline $\begin{array}{l}\text { barrow } \\
\text { groups }\end{array}$ & $\begin{array}{l}\text { period } \\
\text { (years BC) }\end{array}$ & $\begin{array}{l}\text { graves/ } \\
\text { century }\end{array}$ \\
\hline 77 (111) & $1800-1150$ & $12(17)$ \\
\hline 60 & $1150-800$ & 17 \\
\hline
\end{tabular}

population increase of 1.4 (1) times

$\begin{array}{lll}\begin{array}{l}\text { southern Netherlands } \\ \text { barrow } \\ \text { groups }\end{array} & \begin{array}{l}\text { period } \\ \text { (years BC) }\end{array} & \begin{array}{l}\text { graves } \\ \text { century }\end{array} \\ 55 & 1800-1050 & 8 \\ 85 & 1050-800 & 34\end{array}$

population increase of $4 \cdot 25$ times

TABLE 1. An exercise with numbers: a comparison of the numbers of barrows from the Middle Bronze Age and urnfield cemeteries from the Late Bronze Age in the north and the south of the Netherlands. For the northern Netherlands the actual number of known barrows is 253 (365 including second periods with a primary grave). This number is corrected in order to correspond with Roymans' barrow groups. 
FIGURE 4. $A$

comparison of overall

house lengths (in

decending order of

length) from the

Middle and Late

Bronze Age (1800

$900 \mathrm{BC})$ and the Late

Bronze Age-Early

Iron Age (c. 900-550

$B C)$ in the

Netherlands.

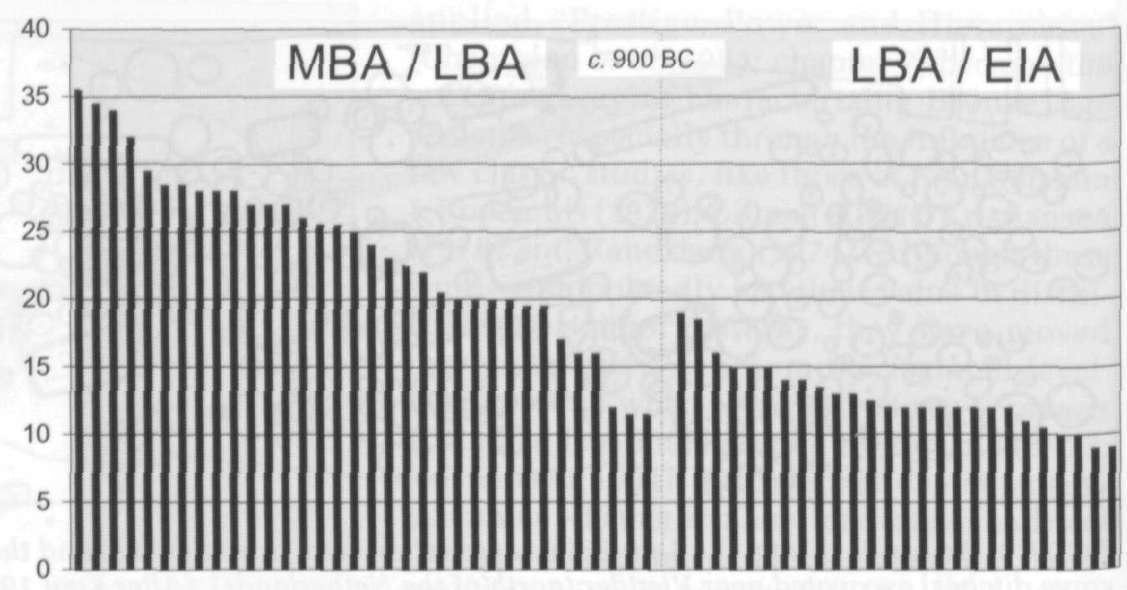

on the low side. Even so, it can easily be demonstrated that the populations using an average urnfield represent only small communities of 10 to 20 people (Kooi 1979: 174; Verlinde 1985: 324). In other words, an urnfield belonged to a group of three or four farms of the small Late Bronze Age type (see below), a group of about the same size as the communities that buried their dead in Middle Bronze Age barrows. Continuity in the use of burial grounds is suggested by the fact that a Middle Bronze Age barrow regularly forms the core of a Late Bronze Age urnfield.

From the above it can be concluded that the larger number of graves in urnfields as compared to the Middle Bronze Age barrows, cannot be used to demonstrate population increase in the Late Bronze Age. Roymans (1991: 67ff), however, observes that urnfields occur in several areas that have no barrows, which in his view demonstrates that the occupation had expanded into previously uninhabited areas. In the area between the rivers Meuse, Demer and Scheldt, for instance, Roymans counted 55 Middle Bronze Age groups of barrows (with c. 180 barrows, inf. E. Theunissen) and 85 Late Bronze Age urnfields (1991: 67). Calculating that in that area 8 Middle Bronze Age barrows were erected per century, against 34 Late Bronze Age urnfields (TABLE 1), he interprets this as proof of a considerable population increase.

This conclusion stands in a different light if one turns to the north of the Netherlands. There substantially more barrows are known: as many as 253 barrows with 365 primary burial phases from the Middle Bronze Age have been recognized (Lohof 1991: 37). Using the same method of calculation only a minor population increase is visible (calculation based on Kooi 1979 (maps); Verlinde 1987: figure 143); a third of 'population growth' in the south.

Actually, I believe that such games with numbers are quite useless because differential destruction should be taken into consideration. Barrows disappear more easily than urnfields; often containing no urns, they are less conspicuous than urnfield graves (e.g. Kooi 1979: 1; Roymans 1991: 66; Fokkens 1991a: chapter 5). Research factors may have been an important source of bias as well (Fokkens 1991a). Therefore, rather than explaining the data of TABLE 1 in terms of population dynamics, we should look at differences in the history of research and reclamation between the north and the south. Together with differences in archaeological visibility, these factors probably can be held responsible for most of the 'observed' developments. In this respect it is revealing that using aerial photography - in the last few years archaeologists from Gand (Belgium) discovered over 600 ditch circles of disappeared Bronze Age barrows in West-Flanders, an area where previously not one barrow was known (Ampe et al. 1995).

\section{Settlement and economy: wandering farmsteads and mixed farming}

Switching now to settlement evidence, the image of culture change is less strong. Since the excavation of the first Middle and Late Bronze Age farms in the 1950s many sites have been discovered in all parts of the Netherlands, allowing us to build a reliable model of the settlement structure and the settlement system 

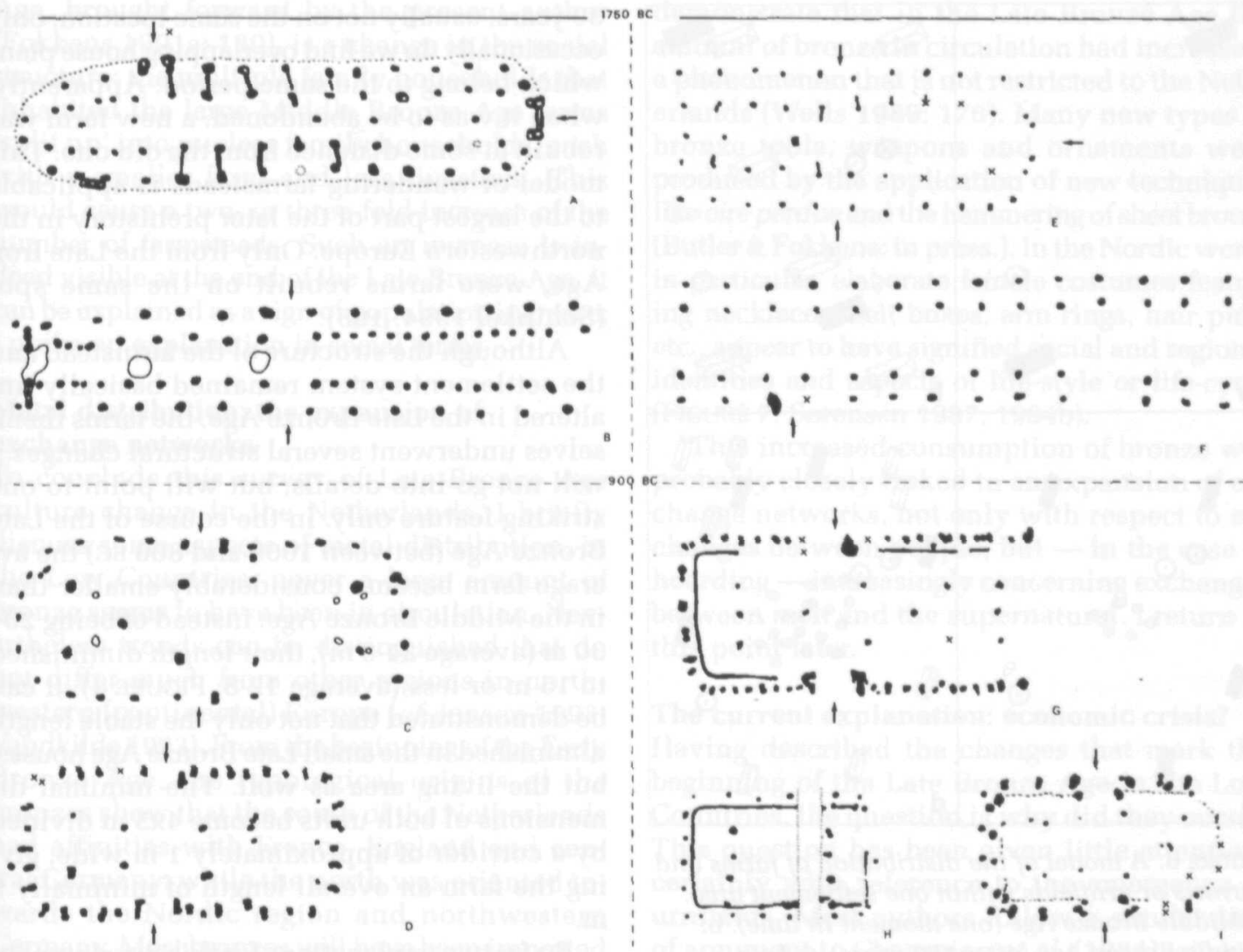

i

FIGURE 5. Comparative survey of house plans from the Middle and Late Bronze Age (top) and the Late Bronze Age-Early Iron Age (below) in the north (left) and the south (right) of the Netherlands (from Roymans \& Fokkens 1991: figure 5).

(Roymans \& Fokkens 1991; Fokkens 1991b). In the Middle Bronze Age, the average farm was a large rectangular building, $5 \times 25 \mathrm{~m}$ or longer (FIGURE 4). Smaller farms also occur, a minority in the presently known number of plans (but see Waterbolk 1986; 1987). Characteristic of this type of farm are a living area and stable combined under one roof. The stalls could hold 2040 head of cattle. When the stalls can be distinguished in the ground plan, which is often not the case, the living area appears to have been just as large as the stable (e.g. FIGURES 5a, 5b), c. 12-15 $\mathrm{m}$ long and $5 \mathrm{~m}$ wide, and could easily have housed a multiple family household of 15-20 persons.

The farmsteads were fenced in with low wattle work fences, which enclosed an area of approximately $50 \times 50 \mathrm{~m}$. Apart from the farm, the farmyards contained a few out-houses of either four or six posts. These structures, common in north-western Europe, are generally interpreted as granaries, although they may have served other purposes. On the higher sand soils, in areas where the ground water table was not too high, grain was also stored in silos, both inside and outside the houses.

Between the north, the south and the west of the Netherlands minor differences in house structure exist, but the basic principles remained the same from the beginning of the Middle Bronze Age (FIGURE 5). In neighbouring countries, like Scandinavia (Jensen 1987; Rasmussen \& Adamsen 1993; Nielsen 1993), northwestern Germany (Wilhelmi 1981), northwestern Belgium (Crombé 1993) and low-lying regions of France (Blouet et al. 1992), almost identical 


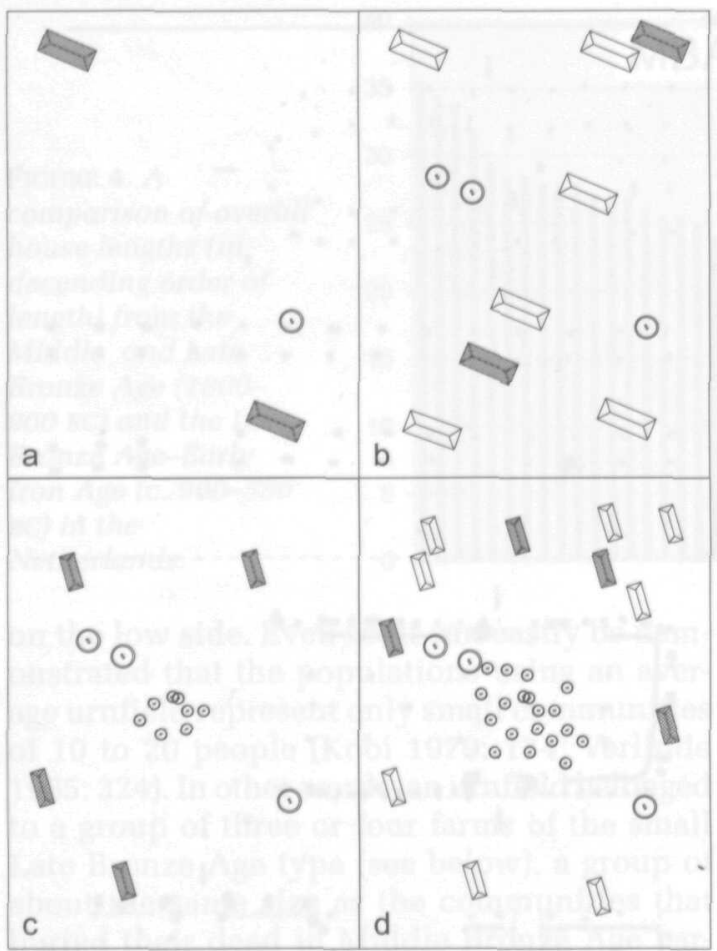

FIGURE 6. A model of the distribution of farms and barrows or urnfields within one settlement area. a: Middle Bronze Age (one moment in time). b: Middle Bronze Age (after 100 years). c: Late Bronze Age (one moment in time). d: Late Bronze Age (after 100 years).

three-aisled farms with stables and four- or sixpost outhouses were common in that period (FIGURE 5). This type was characteristic for the farming system practised in the northwest European lowland plain: a mixed farming economy with an emphasis on cattle breeding. Farms with stables enabled the farmers to collect the dung and to manure the arable land; at the same time they demonstrate the close relationship between the farmer and his cattle, because strictly speaking there is no reason why farmer and cattle should be living under one roof. Roymans (1996) explains this in terms of a pastoral ideology, which in his view characterizes the northwest European lowland plain until the Roman period.

The distribution of the farms across the landscape can be characterised as a system of open settlements consisting of only two or three farmsteads at considerable distance from each other (FIGURE 6). The farms were rebuilt every 20-
30 years, usually not on the same location: only occasionally do we find overlapping house plans which belong to the same period. Apparently, when it was to be abandoned, a new farm was rebuilt at some distance from the old one. This model of wandering farmsteads is applicable to the largest part of the later prehistory in the northwestern Europe. Only from the Late Iron Age, were farms rebuilt on the same spot (Schinkel 1994: 198).

Although the structure of the farmstead and the settlement system remained basically unaltered in the Late Bronze Age, the farms themselves underwent several structural changes. I will not go into details, but will point to one striking feature only. In the course of the Late Bronze Age (between 1000 and $800 \mathrm{BC}$ ) the average farm became considerably smaller than in the Middle Bronze Age: instead of being 20$30 \mathrm{~m}$ (average $24.9 \mathrm{~m}$ ), their length diminished to $15 \mathrm{~m}$ or less (average 12.8; FIGURE 4). It can be demonstrated that not only the stable length diminished in the small Late Bronze Age houses, but the living area as well. The minimal dimensions of both units become $4 \times 5 \mathrm{~m}$ divided by a corridor of approximately $1 \mathrm{~m}$ wide, giving the farm an overall length of minimally 9 $\mathrm{m}$.

So far two explanations for this development have been brought forward. According to Roymans in the Late Bronze Age the role of sheep- and pig-breeding became more important at the expense of the size of the cattle herds. Since sheep and pigs were supposedly kept in pens outside the house smaller stables were needed (Roymans 1990: table 5.4 and 5.5; Roymans 1991: 68; although the majority of his data relates to the La Tène period). Although the bone spectra do indeed show a rise in the relative number of sheep bones, proportionally the role of sheep remains low in comparison to cattle (Lauwerier \& IJzereef 1994: 235; Louwe Kooijmans 1985: 72; Ijzereef 1981: 194). Moreover, there is no evidence that already in the Iron Age extensive heaths existed. Even though we know that the landscape became more open in the Late Neolithic, we have no reason to assume that man had transformed the forested sand soils into vast areas of heath at the end of the Bronze Age (Bakels 1975: 9; Van Zeist 1991: 125).

An alternative explanation for the decline of farm length at the end of the Late Bronze 
Age, brought forward by the present author (Fokkens 1991a: 130), is a change in the social structure: the multiple family households that inhabited the large Middle Bronze Age farms 'split up' into nuclear family households, each with a smaller farm and less livestock. This would cause a two- or three-fold increase of the number of farmsteads. Such an increase is indeed visible at the end of the Late Bronze Age. It can be explained as a sign of population increase; I prefer an explanation in social terms.

\section{Metal distribution: the expansion of exchange networks}

To conclude this survey of Late Bronze Age culture change in the Netherlands, I briefly discuss some aspects of metal distribution. In the Low Countries, never a large amount of bronze seems to have been in circulation. Nevertheless trends can be distinguished that do not differ much from other regions in northwestern (continental) Europe (cf. Jensen 1993; Vandkilde 1993). From the beginning of the Early Bronze Age, the typological origins of the bronzes show that the south of the Netherlands had affinities with France, England and central Germany, while the north was oriented towards the Nordic region and northwestern Germany. Most bronzes will have been imported from those regions, although undoubtedly there also was regional production, predominantly of tools and small weapons (e.g. Butler 1971).

In the Early Bronze Age and Middle Bronze Age A, 2000-1500 BC, the amount of bronzes was relatively small; they occurr in only $11 \%$ of the known graves (Lohof 1994: 108). Only very few graves show a relatively 'rich' assemblage, as for instance the grave of Drouwen, considered richest of the 'Sögel' graves in the Netherlands and northern Germany (Butler 1986; 1990; Lohof 1991). From the later part of the Middle Bronze hardly any Bronze grave gift is known.

In contrast to the earlier periods, the majority of bronze from the Late Bronze Age is found in hoards, often in wet contexts. This development has been noted by many scholars (see Bradley 1990 for references). Moreover, the number of hoards is much greater than in the Early and Middle Bronze Age, which seems to indicate that this practice had grown in popularity (Bradley 1990; Butler 1959: 125). Not only votive deposits in watery locations but also utilitarian hoards on dry land, like scrap hoards, demonstrate that in the Late Bronze Age the amount of bronze in circulation had increased, a phenomenon that is not restricted to the Netherlands (Wells 1989: 176). Many new types of bronze tools, weapons and ornaments were produced by the application of new techniques like cire perdue and the hammering of sheet bronze (Butler \& Fokkens: in press.). In the Nordic world in particular, elaborate female costumes featuring necklaces, belt boxes, arm rings, hair pins, etc., appear to have signified social and regional identities and aspects of life-style or life-cycle (FIGURE 7; Sørensen 1987; 1994b).

This increased consumption of bronze was probably closely linked to an expansion of exchange networks, not only with respect to exchanges between people, but - in the case of hoarding - increasingly concerning exchanges between men and the supernatural. I return to this point later.

\section{The current explanation: economic crisis?}

Having described the changes that mark the beginning of the Late Bronze Age in the Low Countries, the question is why did they occur? This question has been given little attention, certainly with reference to the emergence of urnfields. Most authors follow a similar line of argument to Champion et al. (1984): an economic crisis was the cause of the observed cultural changes, a crisis caused by population growth, resulting in over-exploitation of the available land. According to this Carneiro-like scenario, land became circumscribed. Eventually a more complex society emerged (Carneiro 1970) of which the rich Hallstatt graves of the Early Iron Age are the clearest examples.

Since many authors draw from syntheses such as Prehistoric Europe (Champion et al. 1984), and Prehistoric farming in Europe (Barker 1985), I want to indicate a few of their major misinterpretations. In my opinion, Champion et al. - but Barker as well - often use ecological evidence as if it were absolute data, without exercising enough source criticism. Champion et al. (1984: 270ff) report palynological evidence for agricultural expansion in many parts of Europe (Poland, Scandinavia, French mountainous regions). However, they do not take into consideration that most pollen diagrams represent only a local or at the most micro-regional situation, almost never useful for this type of generalization. 

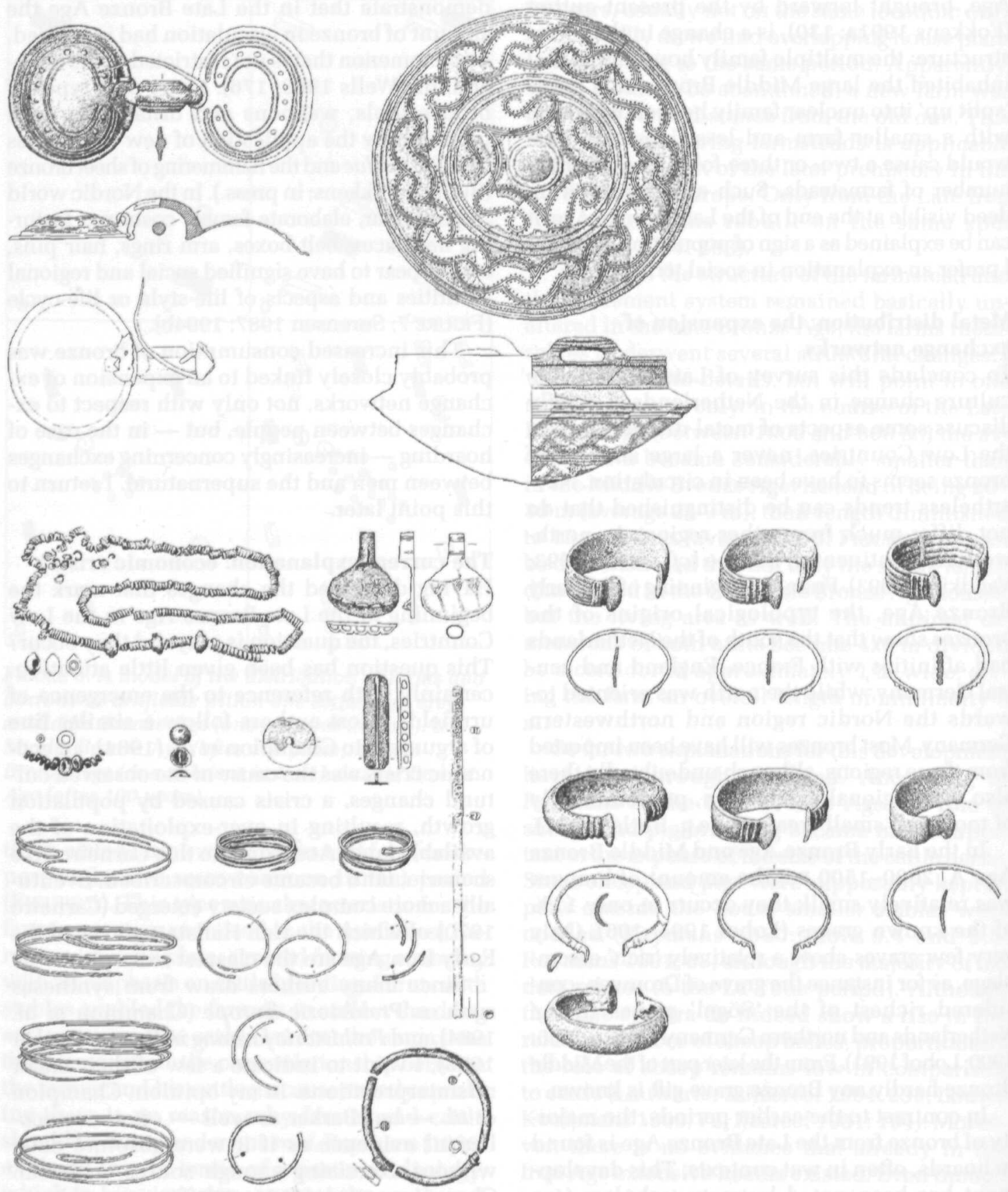

0

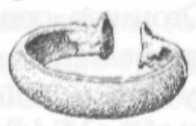

d

ur

at

ch

So

$\mathrm{Br}$

In

Mi

by

of an older barrow. The fibula and the belt box are of Scandinavian origin, the 7 omega-shaped armrings have probably been manufactured locally. (After Butler 1986: figures 20-22.)

In a similar way, climatic deterioration and the expansion of blanket bogs are used as an argument for environmental crisis (Champion et al. 1984: 277). Indeed, formerly occupied areas he

wo

rep

$\sin$ 
became covered by blanket bogs and were therefore uninhabitable; especially in the Netherlands we are aware of this development. Yet peat formation is a slow process that in most areas started long before the 1st millennium BC; there is no reason why this should cause a crisis in that particular period (Fokkens 1991a: 148ff).

The developments interpreted as solutions to the supposed crisis can be criticized just as much. The introduction of new tools like bronze sickles and axes, the increased digging of pits and wells, the construction of granaries and the fixing of field systems are all interpreted as an intensification of production. However, these developments had already begun in the Early and Middle Bronze Age, and extensive settlement research in the Low Countries gives no indication that in the Late Bronze Age there was an increase in the activities mentioned. Similarly Champion et al. (1984: 279) read the concentrations of finds, especially of bronzes, in river valleys as evidence for further expansion into formerly unoccupied areas; yet the concentration of bronzes in the river valleys is predominantly the result of hoarding in wet locations and probably has no relation to actual settlement activities. I could go on demonstrating that much of the idea of economic crises in the Late Bronze Age is based on this type of unsubstantiated generalization, but I think that I have made my point sufficiently clear.

Apart from the problems stated, an economic crisis does not explain why in the Late Bronze Age almost every individual was allowed to become visible as an ancestor, whereas in the Middle Bronze Age only a small selection of the population were entitled to this 'privilege'. Why did the houses become smaller, or why did hoarding practices increase? In order to understand such developments one has to look at ideological and social aspects of prehistoric communities, especially in the context of exchange systems.

\section{Social and ideological aspects of Late Bronze Age culture change}

In previous paragraphs I have argued that the Middle Bronze Age long houses were occupied by multiple family households. Supposedly the head of this domestic group, the eldest man or woman, was the person with authority. S/he represented the household in dealings with other similar groups. In my opinion the same struc- ture is reproduced in the arrangement of the dead in barrows and secondary graves: the head of the household, or of a few households belonging to a kin group, is buried in a primary grave underneath a barrow, his relatives in secondary graves. Settlements and cemeteries therefore depict Middle Bronze Age society in the Low Countries as an assemblage of more or less autonomous communities based on kinship. This structure existed since the genesis of the Beaker Cultures, around 2900 BC, when the Single Grave round barrows replaced the megalithic collective burials of the larger corporate groups of the Middle Neolithic (Barrett 1994: 145ff; Fokkens 1986; in press).

From the beginning of the Late Neolithic the representatives of local communities were probably buried in the neighbourhood of their farmsteads. This is inferred from the wide distribution of barrows in comparison to megalithic graves (Fokkens 1986), although the lack of excavated settlement landscapes debar substantiation of this model. This change from collective tombs to individual barrows marks a fundamental change in ideology. Essential is that the burial ritual does not take place on a predefined spot any longer, the location of the communal grave; the ritual takes place on a different location every time. The new barrow ritual therefore lays emphasis on the identity of the dead person, through the grave gifts, and on the location in the landscape (see Barrett 1994: $47 \mathrm{ff}$ ). The ancestors are not concentrated in a collective tomb any longer; dispersed over the landscape, they claim parts of it for themselves and for their descendants.

In the Late Neolithic and Early Bronze Age these burial locations were exclusive: the barrows often lay solitary and were not used for secondary burials, at least not in the Netherlands (Lohof 1994). If we consider the world of the ancestors an idealized (but incomplete) representation of the world of the living, this exclusiveness could reflect the authority of the dead buried underneath the barrows in the world of the living. In the Middle Bronze Age this situation changed: the barrows became a focus for secondary burial. On the one hand this demonstrates involvement with the ancestor buried in the primary grave and recognizes his ranking; on the other hand it shows a diminished social distance to that person in comparison with earlier practice. 
In the Late Bronze Age burial rites this expression of involvement and authority appears again to have been transformed fundamentally. In the urnfields, though grouped in cemeteries, the graves are separated from each other, and secondary burial does not seem to have been practised: almost everyone, regardless of sex, age and status, is now entitled to a primary grave. There are, however, many sizes and forms of urnfield barrows, of burial forms and of cinerary urns. Urnfields, appearing democratic (Childe 1950: 200), in fact reflect more differences in treatment of the dead than were visible before. These differences may have been related to an equal range of status positions in the world of the living, status positions which are not necessarily related to differences in achieved power - there are almost no 'rich' Late Bronze Age urnfield graves - but certainly also to differences in age and sex. A new ideology has emerged which allows practically everyone, infants as well, to be transformed tò ancestors.

In the settlement development we have noted a similar process of increasing 'individualization' - if we follow my explanation of diminishing farm lengths as the splitting of multiple family households into nuclear families. The new ideology emphasizes individuality: but at the same time the collective is not forgotten or dismissed. The urnfields seem - through continuous use - to express the solidarity of a group and to emphasize its territorial history. A consolidation of territorial structure is also expressed by the origination of extensive Celtic fields systems. Both the urnfields and the Celtic fields may have been used by the same local community: groups of 10-20 persons (Waterbolk 1987; but compare Kooi 1979: 175 who thinks that one Celtic field was used by two or three urnfield communities).

It appears that in the Late Bronze Age kin groups, still a fundamental part of the social organization, no longer form the basis for social differentiation. The collectively approved authority of the kin group elders has been replaced by achieved authority of individuals.

\section{Ideology and exchange}

As I have indicated before, these changes in ideology and social organization have to be explained in the context of exchange. By exchange I mean gift-exchange as a complex of transactions between people, and between people and supernatural entities (Bazelmans 1996: 79). In the observed developments we witness an increased production and deposition of bronzes, suggesting an increase in competition for participation in these exchanges. In prestige models this development is seen as an economic process set in motion by a continuous struggle for power. From that perspective hoarding of bronzes has even been interpreted as a deliberate act of the élites artificially to create scarcity in order to maintain their superior position as a provider of bronzes (e.g. Champion et al. 1984: 220).

In my view this approach ignores the meaning that bronze may have had in constituting a person as a member of society (Bazelmans 1996: 21). A sword or a razor are not simply symbols of wealth, but probably were symbols of manhood, of a warrior (Treherne 1995). This approach places the sets of grave gifts and the composition of hoards in an entirely different light, alongside the change in deposition of these sets from graves to rivers and bogs in the Late Bronze Age and back to graves in the Hallstatt $\mathrm{C}$ period. These complex transformations in exchange ideology are part of a more extensive study by David Fontijn that has recently started in the context of a joint project of the Universities of Leiden and Amsterdam (Fontijn: in preparation). In this article I emphasize only the aspect of increased individualization and competition, also in exchange networks.

Until the Late Bronze Age people lived in relatively large domestic groups represented in contacts with the outside world by their elders who determined the social network created through exchanges. In the Low Countries there is no evidence for chiefs acting as representatives of tribes or subtribes and subsequently redistributing bronzes among their subordinates, a model often suggested for other areas.

In the Late Bronze Age the number of actors in the social field and therefore also in the exchange system appears to have multiplied: many more hoards are being deposited; all people are entitled to a single grave; nuclear families have become the prime household unit. I see these developments as part of the same process. The authority of the traditional leaders in matters of exchange is replaced by autonomy of the nuclear family. There is no longer an a priori consensus about who represents the larger so- 
cial group, and competition arises over that status. Personal ability to create social contacts through gift-exchange and to obtain the benevolence of the gods through ritual deposition becomes important. Ritual deposition may have increased because it has a two-way effect: as an exchange with the gods, it is beneficial to the community as a whole. By the same token it brings prestige to the principal actor, seen as the negotiator between gods and men. Therefore, much more then burial ritual, ritual deposition can be susceptible to manipulation. Maybe that is one reason why in the later Middle Bronze Age the emphasis of deposition shifts from burial to hoards.

There is yet another shift to be witnessed in the use of bronzes : in the course of the Middle Bronze Age the number of grave goods in secondary (female) graves increases at the expense of the bronzes in primary (male) graves (Lohof 1994: 110). Lohof (1994: 117) interprets this as a sign of the increasing importance of women in society:

The social position of the group is no longer legitimized by the person buried centrally in the mound, but through the status of the wives or women acquired through the alliance network that was controlled by men.

Although from a gender perspective this may not be a valuable statement, I agree with Lohof in this respect. It has been demonstrated that, apart from gender- specific symbolism, bronzes are used by women to signify regional identi-

\section{References}

AMPE, C. et al. 1995. Cirkels in het land. Een inventaris van cirkelvormige structuren in de provincies Oost-en WestVlaanderen, Gent: Archeologische Inventaris Vlaanderen. Archeologische inventaris Vlaanderen, buitengewone reeks 4.

B AKELS, C.C. 1975. Pollen spectra from the Late Bronze Age urnfield at Hilvarenbeek-Laag Spul, prov. NoordBrabant, Netherlands, Analecta Praehistorica Leidensia 8: $45-51$.

BARKER, G. 1985. Prehistoric farming in Europe. Cambridge: Cambridge University Press.

BARRETT, J.C. 1994. Fragments from antiquity: an archaeology of social life in Britain, 2900-1200 BC. Oxford: Blackwell.

BAZELMANS, J. 1996. Eén voor allen, allen voor één. Tacitus' Germania, de oudengelse Beowulf en het ritueelkosmologisch karakter van de relatie tussen heer en krijgervolgeling in Germaanse samenlevingen. Ph.D thesis. Department of Archaeology, University of Amsterdam.

BloEMERS, T. 1993. Een urnenveld in stuifzandgebied. Het onderzoek op de Boshoverheide bij Weert, in N. Roymans \& F. Theuws (ed.), Een en al zand. Twee jaar graven naar het Brabantse verleden: 12-21. 's-Hertogenbosch: Stichting Brabants Regionale Geschiedbeoefening. ties (Sørensen 1987; 1994b). As symbols of alliances and therefore of successful exchanges women did not hide their (foreign) identity, but proudly displayed it. Costume probably constituted an essential part in the construction of the female gender (see Sørensen 1992; 1994a: 123).

\section{Concluding remarks}

In this paper I have left many questions unanswered: I hope to have demonstrated that an understanding of social and ideological aspects of the Bronze Age society is vital to explaining culture change. This idea, not new, is often neglected. Some people may object that, especially for the Bronze Age, ideology has always played a role in interpretation. Yes, indeed, but it was only one kind of ideology: a 'prestige good ideology' as explanation that reduced local communities to marionettes in power plays on a European scale. I think - for a while we should steer away from that, and analyse the ways in which bronze was used to construct (gender) identities, and how that influenced burial ritual and ritual deposition, our main sources of information. The approaches of Bazelmans (1996) and Treherne (1995) are useful steps.

Acknowledgements. Earlier drafts of this paper have been commented by Jos Bazelmans, Peter van der Broeke, Erik Drenth, David Fontijn, Erik Lohof and Stuart Needham. I want to thank them for their critical remarks. I may not have incorporated all of their comments, but they certainly helped me to formulate my arguments. The English text was corrected by Karen Waugh (Amersfoort).

Blouet, V. et al. 1992. Données récentes sur l'habitat de l'Age du Bronze en Lorraine, in C. Mordant \& A. Richard (ed.). L'habitat et l'occupation du sol à l'âge du Bronze en Europe. Actes du colloque international de Lons-le Saunier 16-19 mai 1990: 177-94. Paris: Comité des Traveaux Historiques et Scientifiques.

BRADLEY, R. 1990. The passage of arms: an archaeological analysis of prehistoric hoards and votive deposits. Cambridge: Cambridge University Press.

BROEKE, P.W. VAN DEN. 1991. Nederzettingsaardewerk uit de late bronstijd in Zuid-Nederland, in Fokkens \& Roymans: 193-211

Butler, J.J. 1959. Vergeten schatvondsten uit de bronstijd, in J.E. Bogaers et al. (ed.), Honderd eeuwen Nederland, Antiquity and Survival II(5-6): 125-42.

1971. Einheimische Bronzebeilproduction im NiederrheinMaasgebiet, Palaeohistoria 15: 319-43.

1986. Drouwen: end of a 'Nordic' rainbow?, Palaeohistoria 28: 133-68.

1990. Bronze Age metal and amber in the Netherlands (I), Palaeohistoria 32: 47-110.

BUTLER, J.J. \& H. FOKKENS. In press. From stone to bronze: the material side of existence, in L.P. Louwe Kooijmans et 
al. (ed.), The prehistory of the Netherlands. Amsterdam: Amsterdam University Press.

BUTLER, J.J. \& H. SARFATIJ. 1971. Another bronze ceremonial sword by the Ploughrescant-Ommerschans smith, Berichten van de Rijksdienst voor het Oudheidkundig Bodemonderzoek 20 21: 301-9.

CARNEIRO, R.L. 1970. A theory of the origin of the state, Science 169: 733-8.

Champion, T. et al. 1984. Prehistoric Europe. London: Academic Press.

CHILDE, V.G. 1950. Prehistoric migrations. Oslo: Aschehoug.

CROMBÉ, P. 1993. De nederzetting uit de midden-bronstijd te Maldegem 'Burkel' (O-Vl?.), Lunula, Archaeologia Protohistorica 1: 3-6. Brussel: Contactgroep Keltische en Komparatíeve Studies.

FOKKENS, H. 1986. From shifting cultivation to short fallow cultivation: Late Neolithic change in the Netherlands reconsidered, in H. Fokkens et al. (ed.), Op zoek naar mens en materiële cultuur: 5-21. Groningen: Biologisch Archeologisch Instituut.

1991a. Verdrinkend landschap: archeologisch onderzoek van het westelijk Fries-Drents Plateau 4400 BC tot 500 AD. Ph.D thesis, Department of Archaeology, Rijksuniversiteit Groningen.

1991b. Bronze Age settlements in the Netherlands, in C. Chevillot \& A. Cyffyn (ed.), Lage du bronze Atlantique, actes du 1er colloque du parc archéologique de Beynac: 77-86. Beynac: Association des Musées du Sarladais.

In press. From the collective to the individual: some thoughts about social and economic change around $3000 \mathrm{BC}$, in M. Edmonds \& C. Richards (ed.), Social life and social change: the Neolithic of northwestern Europe.

FOKKENS, H. \& N. RoYMANS (ed.). 1991. Nederzettingen uit de bronstijd en de vroege ijzertijd in de lage landen. Amersfoort: Rijksdienst voor het Oudheidkundig Bodemonderzoek. Nederlandse Archeologische Rapporten 13.

FoNTIIN, D. 1996. Socializing landscape: second thoughts about the cultural biaography of urnfields, Archaeological DiaJogues 3.1: 77-87.

In preparation. Spatial and ideological aspects of metal deposition in the Bronze Age.

FRANKENSTEIN, S. \& M.J. ROWLANDS. 1978. The internal structure and regional context of early Iron Age society in southwest Germany, Bulletin of the Institute of Archaeology, University of London 15: 73-112.

GILMAN, A. 1981. The development of social stratification in Bronze Age Europe, Current Anthropology 22: 1-23.

GLASBERGEN, W. 1954. Barrow excavations in the Eight Beatitudes, the Bronze Age cemetery between Toterfout \& Halve Mijl, North Brabant, Palaeohistoria 2/3.

HVAss, S. \& B. STORGAARD (ed.). 1993. Digging into the past. 25 years of archaeology in Denmark. Aarhus: Universitetsforlag.

IJZEREEF, G.F. 1981. Bronze Age animal bones from Bovenkarspel the excavation: at het Valkje. Amersfoort: Rijksdienst voor het Oudheidkundig Bodemonderzoek. Nederlandse Oudheden 10.

IJZEREEF, G.F. \& J.F. VAN REGTEREN ALTENA. 1991. Nederzettingen uit de midden-en late bronstijd bij Andijk en Bovenkarspel. in Fokkens \& Roymans: 61-81.

JENSEN, J. 1987. Bronze Age research in Denmark 1970-1985, Journal of Danish archaeology 6: 155-74.

1993. Metal deposits, in Hvass \& Storgaard: $152-8$.

KoOI, P.B. 1979. Pre-Roman urnfields in the north of the Netherlands. Groningen: Wolters-Noordhof.

KRISTIANSEN, K. 1978. The consumption of wealth in Bronze Age Denmark: a study of the dynamics of economic process in tribal societies, in K. Kristiansen \& C. Paludan-Muller (ed.), New Directions in Scandinavian Archaeology: 15890. Copenhagen: National Museum.

1994. The emergence of the European world system in the Bronze Age: divergence, convergence and socíal evolution during the first and second millennia BC in Europe, in K. Kristiansen \& J. Jensen, Europe in the first millennium BC: 7-29. Sheffield: Collis. Sheffield Archaeological Monographs 6.

LAUWERIER, R.C.G.M. \& G.F. IJZEREEF, 1994. Vee en vlees in de nederzettingen in Oss-Ussen (800 v.Chr-250 na.Chr.), in Schinkel: 233-43.

LOHOF, E. 1991. Grafritueel en sociale verandering in de bronstijd van Noordoost-Nederland. Ph.D thesis, Department of Archaeology, University of Amsterdam.

1994. Tradition and change: burial practices in the Late Neolithic and Bronze Age in the northeastern Netherlands, Archaeological Dialogues 1.2: 98-118.

LOUWE KOOIJMANS, L.P. 1985. Sporen in het land: de Nederlandse delta in de prehistorie. Amsterdam: Meulenhof.

LouWE KoOImanS, L.P. et al. In press. The prehistory of the Netherlands. Amsterdam: Amsterdam Univesity Press.

NIELSEN, P.O. 1993. Settlement, in Hvass \& Storgaard: 92-5.

RANDSBORG, K. 1974. Social dimensions of early Bronze Age Denmark: a study in the regulation of cultural systems, Prähistorische Zeitschrift 49: 38-61.

RASMUSSEN, M. \& C. AdAMSEN. 1993. Settlement, in Hvass \& Storgaard: $136-41$.

RENFREW, C. 1973. Monuments, mobilisation and social organisation in Neolithic Wessex, in. C. Renfrew (ed.), The explanation of culture change: 539-58. London: Duckworth.

ROYMANS, N. 1988. Archeologisch onderzoek bij een grintafgraving te Beegden (L.): een eerste verslag, Archeologie in Limburg 35: 95-9 \& 36: 111-16.

1990. Tribal societies in northern Gaul: an anthropological perspective. Amsterdam: Amsterdam University Press. Cingula 12.

1991. Large urnfield societies in the northwest European Plain and the expanding networks of central European Hallstatt groups, in N. Roymans \& F. Theuws (ed.), Images of the past: 9-89. Amsterdam: Amsterdam University Press.

(Ed.). 1996. From the sword to the plough. Regional dynamics in the romanisation of Belgic Gaul and the Rhineland area, in N. Roymans (ed.), From the plough to the sword: three studies on the earliest romanisation of northern Gaul: 9-126. Amsterdam: Amsterdam University Press.

ROYMANS, N. \& H. FOKKENS. 1991. Een overzicht van veertig jaar nederzettingsonderzoek in de Lage Landen, in Fokkens \& Roymans: $1-20$.

Roymans, N. \& F. THEUWS (ed.). 1993. Een en al zand: twee jaar graven naar het Brabantse verleden. 's-Hertogenbosch: Stichting Brabants Regionale Geschiedbeoefening.

SCHINKEL, K. 1994. Zwervende Erven: bewoningssporen in OssUssen uit bronstijd, ijzertijd en Romeinse tijd, opgravingen 1976-1986. Ph.D thesis, Faculty of Pre- and Protohistory, Rijksuniversiteit Leiden.

SøRENSEN, M.L.S. 1987. Material culture and classification: the role of bronze objects in the transition from Bronze Age to Iron Age in Scandinavia, in I. Hodder (ed.), The $a r^{-}$ chaeology of contextual meanings: 90-101. Cambridge: Cambridge University Press.

1992. Gender archaeology and Scandinavian Bronze Age studies, Norwegian Archaeological Review 25(1): 31-49.

1994a. Thoughts on death and gender, Archaeological Dialogues 1(2): 121-3.

$1994 \mathrm{~b}$. You know that what you wear you are: identifying Bronze Age social categories from dress. Paper presented at conference 'The identity of Bronze Age Europe' (London 27-29 October).

THEUnISSEN, E.M. 1993. Once again Toterfout-Halve Mijl, Analecta Praehistoria Leidensia: 29-43.

VANDKILDE, H. 1993. The earliest metalwork, in Hvass \& Storgaard: $145-51$.

VERLINDE, A.D. 1985. Die Gräber und Grabfunde der späten Bronzezeit und frühen Eisenzeit in Overijssel, Berichten van de Rijksdienst voor het Oudheidkundig Bodemonderzoek 35: 231-412. 
Waterbolk, H.T. 1964. The Bronze Age settlement of Elp, Helinium 4: 97-131.

1986. Elp, Hoops Reallexikon der Germanische Altertumskunde: 163-75. Berlin: Walter de Gruyter.

1987. Terug naar Elp, in F.C.J. Ketelaar (ed.), De historie herzien: vijfde bundel 'Historische Avonden': 183-215. Hilversum: Verloren.

WELLS, P.S. 1989. Intensification, entrepreneurship, and cognitive change in the Bronze-Iron Age transition, in M.L.S. Sørensen \& R. Thomas (ed.), The Bronze AgeIron Age transition in Europe: aspects of continuity and change in European societies c. 1200 to $500 \mathrm{BC}$ : 173-83. Oxford: British Archaeological Reports. International series $483(\mathrm{i})$.

WILHELMI, K. 1981. Zwei bronzezeitliche Kreisgrabenfriedhöfe bei Telgte, Kreis Wahrendorf, Münster. Bodenaltertümer Westfalens 17.

ZEIST, W. VAN. 1991. Economic aspects, in W. van Zeist et al. (ed., Progress in Old World palaeoethnobotany: a retrospective view on the occasion of 20 years of the International Work Group for Palaeoethnobotany: 109-30. Rotterdam: Balkema. 